\title{
Professor John Bryden
}

The European Federation of Medical Informatics Association (EFMI) mournes the death of John Bryden, who died $18^{\text {th }}$ July 2012. John was member of the Board as Executive Officer from 1998 to 2008 and in 2009 became Honorary Fellow of EFMI rewarding his tremendous contribution to EFMI. John was a father figure to both Board and Council and a leader in to our domain where he put focus on the health dimension even before health became a global trend. He played a significant part in the development of the Scottish NHS and published a fascinating overview of 40 years of their information services. His contribution to the British, Scottish, and European Health Informatics community will never be forgotten.

In 1987, under the presidency of Rory O'Moore, John received permission from the EFMI, to organise MIE in Glasgow in 1990. At this time, John was a community medicine specialist at Southern General Hospital in Glasgow. John returned to EFMI in 1998 as the UK representative

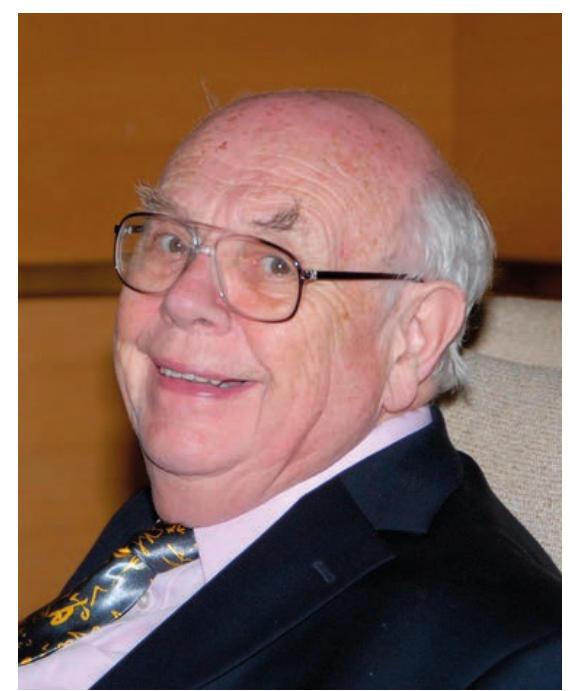

John did much to systematise and professionalise the planning of EFMI conferences. Thanks to his strong involvement in the follow up of the bidding procedure for conference organisation and his considerable energy, we have been able to move from a paper bid book to an electronic system EPOS (EFMI Professional Organised event System).

What characterised John was his bonhomie, his friendly approach and, his wonderful sense of humour. His frank manner of speaking and clear thinking were always greatly appreciated by EFMI Board, Council, and members. After his retirement he became a Scottish Blue Badge Tour Guide qualified to guide in French as well as English. He was very proud to have passed the difficult examination of an official tour guide.

May John's memories give Grace the energy to live for many years in good health! John, we will never forget you and we hope to keep learning from your wisdom. 